\title{
Sosialisasi Tentang Bahaya Narkotika Di Kalangan Sekolah Dasar di Kecamatan Danau Teluk Kota Jambi
}

\author{
Nys. Arfa \\ Fakultas Hukum, Universitas Jambi
}

\begin{abstract}
Abstrak: Di dalam Undang-Undang Nomor 35 Tahun 2014 Tentang Perlindungan Anak ditegaskan bahwa: "Anak adalah tunas, potensi, dan generasi muda penerus cita-cita perjuangan bangsa, memiliki peran strategis yang mempunyai ciri dan sifat khusus yang menjamin kelangsungan eksistensi bangsa dan negara pada masa depan". Salah satu permasalahan anak adalah mengenai penyalahgunaan narkotika. Narkotika yang pada awal mula penggunaannya bertujuan untuk memnuhi perkembangan ilmu pengetahuan dan pelayanan kesehatan, kini keberadaannya menjadi ancaman bagi kelangsungan hidup masyarakat khususnya anak karena disalahgunakan oleh pihak yang tidak bertanggungjawab. Hal ini yang menjadi dasar dari tim pengabdian pada masyarakat untuk ikut berperan aktif dalam memberikan pengetahuan dan pemahaman yang tepat tentang Undang-Undang Narkotika yaitu Undang-Undang Nomor 35 Tahun 2009. Dengan tujuan siswa yang mengikuti penyuluhan hukum dan sosialisasi UU Narkotika yang dilakukan oleh Tim Pengabdian Kepada Masyarakat Fakultas Hukum Universitas Jambi di Sekolah Dasar di Kelurahan Tanjung Pasir Kecamatan Danau Teluk Kota Jambi mengetahuinya tentang bahaya narkotika dan bisa memberikan pemahaman dan penyebaran informasi kepada para guru hingga bisa dicegah untuk melakukan hal-hal yang melanggar Undang-Undang Narkotika atau juga mencegah anak didik jadi korban narkotika yang bisa merusak masa depan anak salah satunya.
\end{abstract}

\section{PENDAHULUAN}

\subsection{Latar Belakang}

Anak sebagai bagian dari generasi muda merupakan penerus cita-cita perjuangan bangsa dan sumber daya manusia bagi pembangunan nasional. Dalam rangka mewujudkan sumber daya manusia yang berkualitas dan mampu memimpin serta memelihara kesatuan dan persatuan bangsa dalam wadah Negara Kesatuan Republik indonesia yang berdasarkan pancasila dan Undang-Undang Dasar 1945, diperlukan pembinaan secara terus menerus demi kelangsungan hidup, pertumbuhaan dan perkembangan fisik, mental, dan sosial serta perlindungan dari segala kemungkinan yang akan membahayakan mereka dan bangsa di masa depan. Masa anak-anak adalah masa yang sangat rawan dalam proses pertumbuhan, karena dimasa-masa inilah anak seringkali memiliki keinginan untuk melakukan sesuatu hal yang baru. Dalam masa pertumbuhan, anak seringkali terpengaruh oleh lingkungan di mana ia bergaul dan bersosialisasi. Lingkungan yang jahat akan membuat anak menjadi jahat.

Di dalam Undang-Undang Nomor 35 Tahun 2014 Tentang Perlindungan Anak ditegaskan bahwa: "Anak adalah tunas, potensi, dan generasi muda penerus cita-cita perjuangan bangsa, memiliki peran strategis yang mempunyai ciri dan sifat khusus yang menjamin kelangsungan eksistensi bangsa dan negara pada masa depan". Karena anak adalah generasi muda yang merupakan penerus cita-cita bangsa dan merupakan sumber daya manusia sebagai faktor penting dalam pelaksanaan pembangunan maka masalah anak merupakan masalah yang sangat penting untuk diperhatikan pemerintah dan masyarakat. 
Salah satu permasalahan anak adalah mengenai penyalahgunaan narkotika. Narkotika yang pada awal mula penggunaannya bertujuan untuk memnuhi perkembangan ilmu pengetahuan dan pelayanan kesehatan, kini keberadaannya menjadi ancaman bagi kelangsungan hidup masyarakat khususnya anak karena disalahgunakan oleh pihak yang tidak bertanggungjawab. Beragam kejahatan seringkali terjadi sebagai dampak dari penyalahgunaan narkotika. Penyalahgunaan narkotika menjadi ancaman yang serius dan mendapat perhatian sebagai tindak pidana yang harus segera diberantas mengingat dampak yang ditimbulkan sangatlah berbahaya.

Secara yuridis penggunaan narkotika hanya digunakan untuk tujuan pengembangan ilmu pengetahuan dan pelayanan kesehatan, namun dalam kenyataan pemakaiannya sering disalahgunakan. Penggunaan narkotika sudah dijadikan sebagai objek bisnis dan berdampak pada kegiatan merusak mental, baik fisik maupun psikis generasi muda.

Terhadap penyalahgunaan narkotika pemerintah mengeluarkan Undang-Undang Nomor 35 Tahun 2009 yang menjadi salah satu wujud realisasi kepedulian pemerintah terhadap masalah penyalahgunaan narkotika.

Betapa bahayanya narkotika jika hal ini dibiarkan akan sangat meresahkan masyarakat dan para orang tua siswa. Untuk itulah dibutuhkan kerja sama semua pihak untuk menyiasati bahaya narkotika.

Hal ini yang menjadi dasar dari tim pengabdian pada masyarakat untuk ikut berperan aktif dalam memberikan pengetahuan dan pemahaman yang tepat tentang Undang-Undang Narkotika yaitu Undang-Undang Nomor 35 Tahun 2009. Dengan tujuan siswa yang mengikuti penyuluhan hukum dan sosialisasi UU Narkotika yang dilakukan oleh Tim Pengabdian Kepada Masyarakat Fakultas Hukum Universitas Jambi di Sekolah Dasar di Kelurahan Tanjung Pasir Kecamatan Danau Teluk Kota Jambi mengetahuinya tentang bahaya narkotika dan bisa memberikan pemahaman dan penyebaran informasi kepada para guru hingga bisa dicegah untuk melakukan hal-hal yang melanggar Undang-Undang Narkotika atau juga mencegah anak didik jadi korban narkotika yang bisa merusak masa depan anak salah satunya. Sedangkan pertimbangan lokasi penelitian di daerah Kelurahan Tanjung Pasir Kecamatan Danau Teluk Kota Jambi adalah lokasi tersebut belum pernah diadakan acara penyuluhan hukum yang temanya tentang narkotika. Dengan diadakan kegiatan ini diharapkan untuk meningkatkan pengetahuan dan pemahaman siswa sekolah dasar tentang jenis-jenis narkotika, sehingga para siswa tahu dan tidak ikut menggunakan atau mencoba narkotika.

Berdasarkan pertimbangan-pertimbangan di atas, Tim Pengabdian Kepada Masyarakat Fakultas Hukum Universitas Jambi bermaksud mengadakan pengabdian pada masyarakat dengan tema "Sosialisasi Tentang Bahaya Narkotika Di Kalangan Siswa Sekolah Dasar Di Kecamatan Danau Teluk Kota Jambi".

\subsection{Rumusan Masalah}

Berdasarkan analisis situasi yang telah diuraikan di atas, maka dirumuskan masalah sebagai berikut:

1. Bagaimana meningkatkan pemahaman bahaya narkotika di kalangan siswa sekolah dasar di kecamatan Danau Teluk Kota Jambi? 
2. Bagaimana pemecahan masalah-masalah yang terjadi dalam lingkungan sekolah berkaitan dengan bahaya narkotika di kalangan siswa sekolah dasar di kecamatan Danau Teluk Kota Jambi?

\subsection{Tujuan Pengabdian Pada masyarakat}

Adapun tujuan yang ingin dicapai dalam penyuluhan hukum ini adalah untuk:

1. Agar para siswa dapat memahami tentang bahaya narkotika dan substansi yang diatur dalam Undang-Undang Nomor 35 Tahun 2009 Tentang Narkotika

2. Memberikan pemecahan permasalahan yang terjadi dalam lingkungan sekolah terkait dengan bahaya narkotika di kalangan siswa sekolah dasar.

\subsection{Manfaat Kegiatan}

Adapun manfaat yang diharapkan dari kegiatan Penyuluhan adalah sebagai berikut:

1. Agar para siswa mengerti dan memahami tentang bahaya narkotika bagi kesehatan dan masa depan siswa, mengetahui bentuk-bentuk perbuatan yang diatur dalam undang-undang sebagai perbuatan yang tergolong sebagai tindak pidana narkotika yang dapat dikenai dengan sanksi pidana. Sebelumnya para siswa belum memahami bahaya narkotika, jenisnarkotika dan perbuatan yang dapat digolongkan sebagai perbuatan pidana yang diatur dalam undang-undang narkotika itu sendiri.

2. Untuk meningkatkan pemahaman dan kesadaran seluruh masyarakat dalam mengatasi terjadinya penyalahgunaan narkotika.

\section{TINJAUAN PUSTAKA}

\subsection{Pengertian Narkotika.}

Secara Etimologi, kata narkotika berasal dari bahasa Yunani yatitu Narke yang artinya terbius sehingga tidak merasakan apa-apa. Sementara menurut vide Keputusan Menteri Kesehatan Republik Indonesia Nomor 2882 Tahun 1970, narkotika diartikan secara umum sebagai semua bahan obat yang umumnya mempunyai efek kerja bersifat membiuskan (dapat menurunkan kesadaran), merangsang (meningkatkan prestasi kerja), menagihkan (meningkatkan ketergantungan), dan menghayal (halusinasi).

Menurut Pasal 1 Angka 1 Undang-Undang Nomor 35 Tahun 2009 Tentang Narkotika, yaitu: "Narkotika adalah zat atau obat yang berasal dari tanaman atau bukan tanaman baik sintetis maupun semi sintetis yang dapat menyebabkan menurunya atau perubahan kesadaran, hilangnya rasa, mengurangi sampai menghilangkan rasa nyeri, dan dapat menimbulkan ketergantungan, yang dibedakan dalam golongan sebagaimana terlampir dalam undangundang ini”.

\subsection{Penggolongan Narkotika}

Menurut Pasal 6 ayat (1) Undang-Undang Nomor 35 Tahun 2009 Tentang Narkotika, penggolongan narkotika yaitu:

a. Narkotika golongan I 
Adalah narkotika yang hanya digunakan untuk tujuan ilmu pengetahuan dan tidak digunakan dalam terapi serta mempunyai potensi yang sangat tinggi mengkibatkan ketergantungan. Yang termasuk dalam golongan ini adalah:

1). Tanaman papaver Somniferum L dan semua bagian-bagiannya termasuk buah dan jeraminya, kecuali bijinya.

2). Opium mentah, yaitu getah yang membeku sendiri, diperoleh dari buah tanaman papaver Somniferum L yang hanya mengalami pengolahan sekedar untuk pembungkus dan pengangkutan tanpa memperhatikan kadar morfinnya.

3). Opium masak, terdiri dari: a). Candu, yang diperoleh dari opium mentah melalui suatu rentetan pengolahan khususnya dengan pelarutan, pemanasan, dan peragian dengan atau tanpa penambahan bahan-bahan lain, dengan maksud mengubahnya menjadi suatu ekstrak yang cocok untuk pemadatan. b). Jicing, sisa-sisa dari candu setelah dihisap, tanpa memperhatikan apakah candu itu dicampur dengan daun atau bahan lain. c). Jicingko, hasil yang diperoleh dari pengolahan jicing.

4). Tanaman Koka, tanaman dari semua genus Erythroxylon dari keluarga Erythroxylaceae termasuk buah dan bijinya.

5). Daun koka, daun yang belum atau sudah dikeringkan atau dalam bentuk serbuk dari semua tanaman genus Erythroxylon dari keluarga Erythroxylaceae yang menghasilkan kokain secara langsung atau melalui perubahan kimia.

6). Kokain mentah, semua hasil yang diperoleh dari daun koka yang dapat diolah secara langsung untuk mendapatkan kokain.

7). Kokaina. Metil ester-1-bensoil ekgonina.

8). Tanaman ganja, semua tanaman genus cannabis dan semua bagian dari tanaman termasuk biji, buah, jerami, hasil olahan tanaman ganja atau bagian tanaman ganja termasuk damar ganja dan hasis.

b. Narkotika golongan II

Adalah narkotika berkhasiat pengobatan digunakan sebagai pilihan terakhir dan dapat digunakan dalam terapai dan/atau untuk tujuan pengembangan ilmu pengetahuan serta mempunyai potensi yang tinggi mengakibatkan ketergantungan. Yang termasuk golongan ini yaitu:

1). Alfasetilmetadol

2). Alfameprodina

3) Alfametadol

4). Alfaprodina

5). Alfentanil

6). Allilprodina

7). Anileridina

8). Asetilmetadol

9). Benzetidin

10). Benzilmorfina

11). Morfina-N-oksida

12). Morfin metobromida dan turunan morfina nitrogen pentafalent lainnya termasuk bagian turunan morfina-N-oksida, salah satunya kodeina-Noksida, dan lain-lain.

c. Narkotika golongan III 
Adalah narkotika berkhasiat pengobatan dan banyak digunakan dalam terapi dan/atau untuk tujuan pengembangan ilmu pengetahuan serta mempunyai potensi ringan mengakibatkan ketergantungan. Yang termasuk ke dalam golongan ini yaitu:

1). Asetildihidrokodeina

2). Dekstropropoksifena

3). Dihidrokodeina

4). Etilmorfina

5). Kodeina

6). Nikodikodina

7). Nokikodina

8). Norkodeina

9). Polkodina

10). Propiram

11). Bufrenorfina

12). Garam-garam dari narkotika dalam golongan tersebut di atas.

13). Campuran atau sediaan difenoksin dengan bahan lain bukan narkotika.

Menurut Wresniworo, bahwa narkotika menurut cara atau proses pengolahannya dapat dibagi ke dalam 3 (tiga) golongan, yaitu:

a. Narkotika alam

Adalah narkotika yang berasal dari hasil olahan tanaman yang dapat dikelompokkan dari 3 (tiga) jenis tanaman masing-masing yaitu:

1). Opium atau candu, yaitu hasil olahan getah dari buah tanaman paper somniferum. Yang termasuk dalam kelompok ini adalag opium mentah, opium masak dan morfin. Jenis opium ini berasal dari luar negeri yang diseludupkan ke Indonesia, karena jenis tanaman ini tidak terdapat di Indonesia.

2). Kokain, yaitu berasal dari olahan daun tanaman koka yang banyak terdapat dan diolah secara gelap di Amerika Bagian selatan seperti Peru, Bolivia, Kolombia.

3). Canabis Sativa atau marihuana atau yang disebut ganja termasuk hashish oil (minyak ganja). Tanaman ganja ini banyak ditanam secara ilegal di daerah khatulistiwa khususnya di Indonesia terdapat di Aceh.

b. Narkotika semi sintetis

Adalah narkotika yang dibuat dari alkoloida opium dengan inti penathren dan diproses secara kimiawi untuk menjadi bahan obat yang berkhasiat sebagai narkotika. Contoh yang terkenal dan sering disalahgunakan adalah heroin dan codein.

c. Narkotika sintetis

Adalah narkotika yag diperolah melalui proses kimia dengan menggunakan bahan baku kimia, sehingga diperoleh suatu hasil baru yang mempunyai efek narkotika seperti Pethidine, Metadon dan megadon.

\subsection{Tindak Pidana Narkotika}

Tindak pidana narkotika adalah serangkaian perbuatan terlarang oleh undang-undang, dan tercela dalam kaitan dengan kegiatan pemakaian dan peredaran atau perdagangan 
penggunaan obat atau zat kimia yang berfungsi menurunkan tingkat kesadaran ingatan atau fisik bahkan menimbulkan masalah dan gangguan kesehatan kejiwaan seseorang, dalam situasi dan kondisi tertentu yang telah terjadi, karenanya dapat dikenakan sanksi fisik maupun moral bahkan perampasan kekayaan bagi pelakunya.

Ketentuan tentang larangan yang tergolong sebagai tindak pidana narkotika terdapat dalam Bab XV Pasal 111 sampai dengan Pasal 148 Undang-Undang Nomor 35 Tahun 2009 Tentang Narkotika.

Pasal 111

(1) Setiap orang yang tanpa hak atau melawan hukum menanam, memelihara, memiliki, menyimpan, menguasai, atau menyediakan Narkotika Golongan I dalam bentuk tanaman, dipidana dengan pidana penjara paling singkat 4 (empat) tahun dan paling lama 12 (dua belas) tahun dan pidana denda paling sedikit Rp. 800.000.000,00 (delapan ratus juta rupiah) dan paling banyak Rp. 8.000.000.000,00 (delapan milyar rupiah).

(2) Dalam hal perbuatan menanam memelihara, memiliki, menyimpan, menguasai, atau menyediakan Narkotika Golongan I dalam bentuk tanaman sebagaimana dimaksud pada ayat (1) beratnya melebihi 1 (satu) kilogram atau melebihi 5 (lima) batang pohon, pelaku dipidana dengan pidana penjara seumur hidup atau pidana penjara paling singkat 5 (lima) tahun dan paling lama 20 (dua puluh) tahun dan pidana denda maksimum sebagaimana dimaksud pada ayat (1) ditambah 1/3 (sepertiga).

Pasal 112

(1) Setiap orang yang tanpa hak atau melawan hukum memiliki, menyimpan, menguasai, atau menyediakan Narkotika Golongan I bukan tanaman, dipidana dengan pidana penjara paling singkat 4 (empat) tahun dan paling lama 12 (dua belas) tahun dan dipidana denda paling sedikit Rp. 800.000.000,00 (delapan ratus juta rupiah) dan paling banyak Rp. 8.000.000.000.00 (delapan milyar rupiah).

(2) Dalam hal perbuatan memiliki, menyimpan, menguasai, atau menyediakan Narkotika Golongan I bukan tanaman sebagaimana dimaksud pada ayat (1) beratnya melebihi 5 (lima) gram, pelaku dipidana dengan pidana penjara seumur hidup atau pidana penjara paling singkat 5 (lima) tahun dan paling lama 20 (dua puluh) tahun dan pidana denda maksimum sebagaimana dimaksud pada ayat (1) ditambah 1/3 (sepertiga).

Pasal 113

(1) Setiap orang yang tanpa hak atau melawan hukum memproduksi, mengimpor, mengeksport atau menyalurkan Narkotika Golongan I, dipidana dengan pidana penjara paling singkat 5 (lima) tahun dan paling lama 15 (lima belas) tahun dan pidana denda paling sedikit Rp. 1.000.000.000,00 (satu milyar rupiah) dan paling banyak Rp. 10.000.000.000,00 (sepuluh mulyar rupiah).

(2) Dalam hal perbuatan memproduksi, mengeksport atau menyalurkan Narkotika Golongan I sebagaimana dimaksud pada ayat (1) dalam bentuk tanaman beratnya melebihi 1 (atu) kilogram atau melebihi 5 (lima) batang atau dalam bentuk bukan tanaman beratnya melebihi 5 (lima) gram, pelaku dipidana dengan pidana mati, pidana penjara seumur hidup, atau pidana penjara paling singkat 5 (lima) tahun dan paling lama 20 (dua puluh) tahun dan pidana denda maksimum sebagaimana dimaksud pada ayat (1) ditambah 1/3 (sepertiga). 


\section{Pasal 114}

(1) Setiap orang yang tanpa hak atau melawan hukum menawarkan untuk dijual, menjual, membeli, menerima, menjadi perantara dalam jual beli, menukar, atau menyerahkan Narkotika Golongan I, dipidana dengan pidana penjara seumur hidup atau pidana penjara paling singkat 5 (lima) tahun dan paling lama 20 (dua puluh) tahun dan pidana denda paling sedikit Rp. 1.000.000.000,00 (satu milyar rupiah) dan paling banyak Rp. 10.000.000.000,00 (sepuluh milyar rupiah).

(2) Dalam hal perbuatan menawarkan untuk dijual, membeli, menukar, menyerahkan, atau menerima Narkotika Golongan I sebagaimana dimaksud pada ayat (1) yang dalam bentuk tanaman beratnya melebihi 1 (satu) kilogram atau melebihi 5 (lima) batang pohon atau dalam bentuk bukan tanaman beratnya melebihi 5 (lima) gram, pelaku dipidana dengan pidana mati, pidana penjara seumur hidup, atau pidana penjara paling singkat 6 (enam) tahun dan paling lama 20 (dua puluh) tahun dan pidana denda maksimum sebagaimana dimaksud pada ayat (1) ditambah 1/3 (sepertiga).

Pasal 115

(1) Setiap orang yang tanpa hak atau melawan hukum membawa, mengirim, mengangkut, atau mentransito Narkotika Golongan I, dipidana dengan pidana penjara paling singkat 4 (empat) tahun dan paling lama 12 (dua belas) tahun dan pidana denda paling sedikit Rp. 800.000.000,00 (delapan ratus juta rupiah) dan paling banyak Rp. 8.000.000.000,00 (delapan milyar rupiah).

(2) Dalam hal perbuatan membawa, mengirim, mengangkut, atau mentransito Narkotika Golongan I sebagaima a dimaksud pada ayat (1) dalam bentuk tanaman beratnya melebihi 1 (satu) kilogram atau melebihi 5 (lima) batang pohon atau bukan tanaman beratnya melebihi 5 (lima) gram, pelaku dipidana dengan pidana penjara seumur hidup atau pidana penjara paling singkat 5 (lima) tahun dan paling lama 20 (dua puluh) tahun dan pidana denda maksimum sebagaimana dimaksud pada ayat (1) ditambah 1/3 (sepertiga).

Pasal 116

(1) Setiap orang yang tanpa hak atau melawan hukum menggunakan Narkotika Golongan I terhadap orang lain atau memberikan Narkotika Golongan I untuk digunakan orang lain, dipidana dengan pidana penjara paling singkat 5 (lima) tahun dan paling lama 15 (lima belas) tahun dan pidana denda paling sedikit Rp. 1.000.000.000,00 (satu milyar rupiah) dan paling banyak Rp. 10.000.000.000,00 (sepuluh milyar rupiah).

(2) Dalam hal penggunaan Narkotika Golongan I untuk digunakan orang lain sebagaimana dimaksud pada ayat (1) mengakibatkan orang lain mati atau cacat permanen, pelaku dipidana dengan pidana mati, pidana penjara seumur hidup, atau pidana penjara paling singkat 5 (lima) tahun dan paling lama 20 (dua puluh) tahun dan pidana denda maksimum sebagaimana dimaksud pada ayat (1) ditambah 1/3 (sepertiga).

Pasal 117

(1) Setiap orang yang tanpa hak atau melawan hukum memiliki, menyimpan, menguasai, atau menyediakan Narkotika Golongan II, dipidana dengan pidana penjara paling singkat 3 (tiga) tahun dan paling lama 10 (sepuluh) tahun dan pidana denda paling sedikit Rp. 600.000.000,00 (enam ratus juta rupiah) dan paling banyak Rp. 5. 000.000.000,00 (lima milyar rupiah). 
(2) Dlam hal perbuatan memiliki, menyimpan, menguasai, atau menyediakan Narkotika Golongan II sebagaimana dimasud pada ayat (1) beratnya melebihi 5 (lima) gram, pelaku dipidana dengan pidana penjara paling singkat 5 (lima) tahun dan paling lama 15 (lima belas) tahun dan pidana denda maksimum sebagaimana dimaksud pada ayat (1) ditambah $1 / 3$ (sepertiga).

Pasal 118

(1) Setiap orang yang tanpa hak atau melawan hukum memproduksi, mengimpor, mengekspor atau menyalurkan Narkotika Golongan II, dipidana dengan pidana penjara paling singkat 4 (empat) tahun dan paling lama 12 (dua belas) tahun dan pidana denda paling sedikit Rp. 800.000.000,00 (delapan ratus juta rupiah) dan paling banyak Rp. 8.000.000.000,00 (delapan milyar rupiah).

(2) Dalam hal perbuatan memproduksi, mengimpor, mengekspor atau menyalurkan Narkotika Golongan II sebagaimana dimaksud pada ayat (1) beratnya melebihi 5 (lima) gram, pelaku dipidana dengan pidana penjara seumur hidup, atau pidana penjara paling singkat 5 (lima) tahun dan paling lama 20 (dua puluh) tahun dan pidana denda maksimum sebagaimana dimaksud pada ayat (1) ditambah 1/3 (sepertiga).

Pasal 119

(1) Setiap orang yang tanpa hak atau melawan hukum menawarkan untuk dijual, menjual, membeli, menerima, menjadi perantara dalam jual beli, menukar, atau menyerahkan Narkotika Golongan II, dipidana dengan pidana penjara paling singkat 4 (empat) tahun dan paling lama 12 (dua belas) tahun dn pidana denda paling sedikit Rp. 800.000.000,00 (delapan ratus juta rupiah) dan paling banyak Rp. 8.000.000.000,00 (delapan milyar rupiah).

(2) Dalam hal perbuatan menawarkan untuk dijual, menjual, membeli, menerima, menjadi perantara dalam jual beli, menukar, atau menyerahkan Narkotika Golongan II sebagaimana dimaksud pada ayat (1) beratnya melebihi 5 (lima) gram, pelaku dipidana dengan pidana mati, pidana penjara seumur hidup, atau pidana penjara paling singkat 5 (lima) tahun dan paling lama 20 (dua puluh) tahun dan pidana denda maksimum sebagaimana dimaksud pada ayat (1) ditambah 1/3 (sepertiga).

Pasal 120

(1) Setiap orang yang tanpa hak atau melawan hukum membawa, mengirim, mengangkut, atau mentransito Narkotika Golongan II, dipidana dengan pidana penjara paling singkat 3 (tiga) tahun dan paling lama 10 (sepuluh) tahun dan pidana denda paling sedikit Rp. 600.000.000,00 (enam ratus juta rupiah) dan paling banyak Rp. $5.000 .000 .000,00$ (lima milyar rupiah).

(2) Dalam hal perbuatan membawa, mengirim, mengangkut, atau mentransito Narkotika Golongan II sebagaimana dimaksud pada ayat (1) beratnya melebihi 5 (lima) gram maka pelaku dipidana dengan pidana penjara paling singkat 5 (lima) tahun dan paling lama 15 (lima belas) tahun dan pidana denda maksimum sebagaimana dimaksud pada ayat (1) ditambah $1 / 3$ (sepertiga).

Pasal 121

(1) Setiap orang yang tanpa hak atau melawan hukum menggunakan Narkotika Golongan II terhadap orang lain atau memberikan Narkotika Golongan II untuk digunakan orang lain, dipidana dengan pidana penjara paling singkat 4 (empat) tahun dan paling lama 12 (dua 
belas) tahun dan pidana denda paling sedikit Rp. 800.000.000,00 (delapan ratus juta rupiah) dan paling banyak Rp. 8.000.000.000,00 (delapan milyar rupiah).

(2) Dalam hal penggunaan narkotika terhadap orang lain atau pemberian Narkotika Golongan II untuk digunakan orang lain sebagaimana dimaksud pada ayat (1) mengakibatkan orang lain mati atau cacat permanen, pelaku dipidana dengan pidana mati, pidana penjara seumur hidup, atau pidana penjara paling singkat 5 (lima) tahun dan paling lama 20 (dua puluh) tahun dan pidana denda maksimum sebagaimana dimaksud pada ayat (1) ditambah $1 / 3$ (sepertiga).

Pasal 122

(1) Setiap orang yang tanpa hak atau melawan hukum memiliki, menyimpan, menguasai, atau menyediakan Narkotika Golongan III, dipidana dengan pidana pejara paling singkat 2 (dua) tahun dan paling lama 7 (tujuh) tahun dan pidana denda paling sedikit Rp. 4.00.000.000,00 (empat ratus juta rupiah) dan paling banyak Rp. 3. 000.000.000,00 (tiga milyar rupiah).

(2) Dalam hal perbuatan memiliki, menyimpan, menguasai, atau menyediakan Narkotika Golongan III sebagaimana dimaksud pada ayat (1) beratnya melebihi 5 (lima) gram, pelaku dipidana dengan pidana penjara paling singkat 3 (tiga) tahun dan paling lama 10 (sepuluh) tahun dan pidana denda maksimum sebagaimana dimaksud pada ayat (1) ditambah $1 / 3$ (sepertiga).

Pasal 123

(1) Setiap orang yang tanpa hak atau melawan hukum memproduksi, mengimpor, mengekspor, atau menyalurkan Narkotika Golongan III, dipidana dengan pidana penjara paling singkat 3 (tiga) tahun dan paling lama 10 (sepuluh) tahun dan pidana denda paling sedikit Rp. 600.000.000,00 (enam ratus juta rupiah) dan paling banyak Rp 5.000.000.000,00 (lima milyar rupiah).

(2) Dalam hal perbuatan memproduksi, mengimpor, mengekspor, atau menyalurkan Narkotika Golongan III sebagaimana dimaksud pada ayat (1) beratnya melebihi 5 (lima) gram, pelaku dipidana dengan pidana penjara paling singkat 5 (lima) tahun dan paling lama 15 (lima belas tahun) dan pidana denda maksimum sebagaimana dimaksud pada ayat (1) ditambah $1 / 3$ (sepertiga).

Pasal 124

(1) Setiap orang yang tanpa hak atau melawan hukum menawarkan untuk dijual, menjual, membeli, menerima, menjadi perantara dalam jual beli, menukar, atau menyerahkan Narkotika Golongan III, dipidana dengan pidana penjara paling singkat 3 (tiga) tahun dan paling lama 10 (sepuluh) tahun dan pidana denda paling sedikit Rp. 600.000.000,00 (enam ratus juta rupiah) dan paling banyak Rp. 5.000.000.000,00 (lima milyar rupiah)

(2) Dalam hal perbuatan menawarkan untuk dijual, menjual, membeli, menerima, menjadi perantara dalam jual beli, menukar, atau menyerahkan Narkotika Golongan III sebagaimana dimaksud pada ayat (1) beratnya melebihi 5 (lima) gram, pelaku dipidana dengan pidana penjara paling singkat 5 (lima) tahun dan paling lama 15 (lima belas) tahun dan pidana denda maksimum sebagaimana dimaksud pada ayat (1) tambah $1 / 3$ (sepertiga).

Pasal 125 
(1) Setiap orang yang tanpa hak atau melawan hukum membawa, mengirim, mengangkut atau mentransito Narkotika Golongan III, dipidana dengan pidana penjara paling singkat 2 (dua) tahun dan paling lama 7 (tujuh) tahun dan pidana denda paling sedikit Rp. 4.00.000.000,00 (empat ratus juta rupiah) dan paling banyak Rp. 3.000.000.000,00 (tiga milyar rupiah).

(2) Dalam hal perbuatan hukum membawa, mengirim, mengangkut atau mentransito Narkotika Golongan III sebagaimana dimaksud pada ayat (1) beratnya melebihi 5 (lima) gram, pelaku dipidana dengan pidana penjara paling singkat 3 (tiga) tahun dan paling lama 10 (sepuluh) tahun dan pidana denda maksimum sebagaimana dimaksud pada ayat (1) ditambah $1 / 3$ (sepertiga).

\section{Pasal 126}

(1) Setiap orang yang tanpa hak atau melawan hukum menggunakan Narkotika Golongan III terhadap orang lain atau memberikan Narkotika Golongan III untuk digunakan orang lain, dipidana dengan pidana penjara paling singkat 3 (tiga) tahun dan paling lama 10 (sepuluh) tahun dan pidana denda paling sedikit Rp. 600.000.000,00 (enam ratus juta rupiah) dan paling banyak Rp. 5.000.000.000,00 (lima milyar rupiah).

(2) Dalam hal penggunaan narkotika terhadap orang lain atau pemberian Narkotika Golongan III untuk digunakan orang lain sebagaimana dimaksud pada ayat (1) mengakibatkan orang lain mati atau cacat permanen, pelaku dipidana dengan pidana penjara paling singkat 5 (lima) tahun dan paling lama 15 (lima belas) tahun dan pidana denda maksimum sebagaimana dimaksud pada ayat (1) ditambah $1 / 3$ (sepertiga).

Pasal 127

(1) Setiap penyalahguna:

a. Narkotika Golongan I bagi diri sendiri dipidana dengan pidana penjara paling lama 4 (empat) tahun;

b. Narkotika Golongan II bagi diri sendiri dipidana dengan pidana penjara paling lama 2 (dua) tahun; dan

c. Narkotika Golongan III bagi diri sendiri dipidana dengan pidana penjara paling lama 1 (satu) tahun.

(2) Dalam memutus perkara sebagaimana dimaksud pada ayat (1), hakim wajib memperhatikan ketentuan sebagaimana dimaksud dalam Pasal 54, Pasal 55, dan Pasal 103.

(3) Dalam hal penyalahguna sebagaimana dimaksud pada ayat (1) dapat dibuktikan atau terbukti sebagai korban penyalahgunaan narkotika, penyalahguna tersebut wajib menjalani rehabilitasi media dan rehabilitasi sosial.

\section{PEMBAHASAN}

\subsection{Persiapan Pengabdian Pada Masyarakat}

Untuk kelancaran pelaksanaan pengabdian pada masyarakat ini perlu dilakukan persiapan-persiapan. Dimulai dari perencanaan sampai dengan pelaksanaannya. Hal ini dimaksudkan supaya pelaksanaan dapat berjalan lancar.

\section{a. Perencanaan}

Ada pun persiapan itu dimulai penjajakan terhadap kemungkinan pelaksanaan penyuluhan di Sekolah Dasar Kecamatan Danau Teluk kota Jambi terpilih dengan melakukan observasi dan wawancara dengan kepala sekolah. Selanjutnya hasil penjajakan dipergunakan 
untuk menyusun materi, jadual kegiatan serta menentukan kelayak sasaran. Dari hasil penjajakan dipilih Sekolah Dasar Negeri 7/IV Desa Tanjung Pasir Kecamatan Danau Teluk.

\section{b. Pelaksanaan Pengabdian Pada Masyarakat}

Pengabdian Pada Masyarakat dalam bentuk penyuluhan hukum dilaksanakan setelah adanya kesepakatan antara penyuluh hukum (Tim Pengabdian Pada Masyarakat Fakultas Hukum Universitas Jambi dengan Kepala Sekolah Dasar Negeri 7/IV di desa Tanjung Pasir Kecamatan Danau Teluk kota Jambi tentang penentuan hari, tanggal dan waktu penyuluhan. Maka berdasarkan kesepakatan tersebut diadakanlah penyuluhan hukum pada hari Jum'at tanggal 15 September 2017 dari pukul 09.30 WIB sampai dengan selesai bertempat di Sekolah Dasar Negeri 7/IV desa Tanjung Pasir Kecamatan Danau Teluk kota Jambi.

Dengan tenaga penyuluh sebagai berikut:

1. Nys. Arfa, S.H.,M.H.

2. Elizabeth Siregar, S.H.,M.H.

\section{c. Peserta Penyuluhan}

1. Para siswa

2. Guru

\subsection{Materi dan Metode}

\section{Faktor-faktor penyebab penyalahgunaan narkotika.}

Ada beberapa faktor penyebab seseorang menyalahgunakan narkotika, yaitu:

1. Faktor individu

Faktor individu antara lain adalah:

a. Aspek kepribadian

b. Kecemasan dan depresi

c. Aspek pengetahuan, sikap dan kepercayaan

d. Keterampilan berkomunikasi

e. Faktor emosional dan mental

2. Faktor sosial budaya

Faktor sosial budaya antara lain adalah:

a. Kondisi keluarga

b. Pengaruh teman sebaya

3. Faktor lingkungan di sekolah

Faktor lingkungan disekolah antara lain adalah:

a. Tempat berkumpulnya anak-anak sekolh

b. Tidak ada kebijakan disekolah tentang narkoba

c. Tidak ada tata tertib disekolah tentang narkoba

4. Faktor lain lingkungan

a. Pengaruh dari lorang dilingkungan rumah yang sering berbuat negatif

b. Pengaruh kemajuan teknologi

\section{Akibat Penyalahgunaan Narkotika}


Penyalahgunaan narkotika akan menimbulkan akibat terutama bagi penyalahguna itu sendiri, diantara akibat yang ditimbulkan dari penyalahgunaan tersebut yaitu:
a. Bagi kesehatan akan mengakibatkan penyakit AIDS, penyakit paru-paru, jantung, hepatitis bahkan dapat mengakibatkan over dosis.
b. Mengakibatkan terjadinya kriminalitas seperti kekerasan dan kejahatan lain.
c. Kemungkinan akan mengakibatkan putus sekolah, dan
d. Gangguan jiwa

Bagi penyalahguna narkotika ini sendiri akan memungkinkan timbulnya sikap emosional, perasa dan gampang tersinggung, mudah marah tanpa sebab, tidak peruli dengan perasaan orang lain, pelupa atau menururnnya daya ingat

\section{Cara Penanggulangan Penyalahgunaan Narkotika di kalangan siswa.}

Untuk menghindari terjadinya penyalahgunaan Narkotika, diperlukan cara-cara penanggulangan penyalahgunaan nakotika, antara lain:

a. Dari diri siswa sendiri dapat dilakukan dengan cara persiapan diri dan mental untuk menolak atau berkata tidak untuk narkoba, memiliki cita-cita dalam hidup dan masa depan, melakukan kegiatan positif, membut pekerjaan yang berguna untuk orang lain dan lingkungan.

b. Peran dari orang tua tidak kalah pentingnya dalam pencegahan terjadinya penyalahgunaan narkotika, diantaranya dapat dilakukan dengan ikut terlibat dalam kegiatan anak-anak mereka, mendekatkan komunikasi dengan anak, memberikan contoh teladan yang baik dalam kehidupan sehari-hari bagi anak, membuat aturan yang jelas dan tegas dalam keluarga, mengembangkan tradisi keluarga dan nilai-nilai agama dalam keluarga dan tak kalah pentingnya posisi orang tua sebagai pembimbing dan pendidik bagi anak.

c. Peran pihak sekolah dalam pencegahan terjadinya penyalahgunaan narkotika dapat dilakukan dengan menetapkan dan melaksanakan kebijakan penanggulangan, melaksanakan kurikulum pendidikan pencegahan, melakukan pendidikan dan pelatihan para guru dan tentang pencegahan penyalahgunaan narkotika, dan lain-lain.

\section{KESIMPULAN}

Kegiatan Penyuluhan hukum ini bertujuan agar siswa sekolah dasar mengerti dan memahami tentang bahaya narkotika, jenis serta pengaturan tentang narkotika yang diatur dalam undang-undang, untuk meningkatkan pemahaman dan pengetahuan seluruh masyarakat khususnya guru dan siswa sekolah dasar dalam mengatasi terjadinya penyalahgunaan narkotika. Penanggulangan dan pencegahan penyalahgunaan narkotika yang salah satunya terjadi dalam lingkup sekolah dasar merupakan tanggungjawab guru dan siswa. Peran guru dan siswa sangat diperlukan dalam menanggulangi terjadinya penyalahgunaan narkotika, seandainya terjadi penyalahgunaan narkotika maka merupakan tanggungjawab kita bersama untuk mencegah dan menanggulangi terjadinya penyalahgunaan nerkotika tersebut.

Agar penyalahgunaan narkotika tidak terjadi maka:

1. Harus ada sosialisasi mengenai bahaya dan pengaturan tentang narkotika,agar masyarakat khususnya siswa sekolah dasar mengerti dan memahami tentang bahaya narkotika itu sendiri. 
2. Meningkatkan kesadaran siswa sekolah dasar akan pentingnya menjaga diri dari tindakan penyalahgunaan narkotika.

\section{DAFTAR PUSTAKA}

\section{BUKU}

Abintoro Prakoso, 2013, Kriminologi Dan Hukum Pidana, Laksbang Grafika.

Barda Nawawi Arief, 2008, Masalah Penegakan Hukum Dan Kebijakan Hukum Pidana Dalam Penanggulangan Kejahatan, Edisi Revisi, Cetakan Kesatu, Prenada Media Group, Jakarta.

Ramli Atmasasmita, 1992, Teori Dan Kapita Selekta Kriminologi, PT. Eresco, Bandung.

Soejono Soekanto, 1987, Penanggulangan Kejahatan, Politea, Bogor.

Siswanto Sunarso, 2005, Penegakan Hukum Psikotropika Dalam Kajian Sosiologis Hukum, Raja Grafindo Persada, Jakarta.

Soediono. D., 1983, Penanggulangan Kejahatan, Alumni, Bandung.

Tanti Yuniar, 1992, Kamus Lengkap Bahasa Indonesia, Agung Media Mulia.

\section{Perundang-undangan}

Kitab Undang-Undang Hukum Pidana

Republik Indonesia, Undang-undang Tentang Narkotika, UU Nomor 35 Tahun 2009. 